\title{
Strengthening the Religious Moderation through Innovation of Islamic Religious Education (IRE) based Civic Intelligence and the Values Clarification Technique (VCT)
}

\author{
Titis Thoriquttyas ${ }^{1}$, Meidi Saputra ${ }^{2}$, Imamul Huda ${ }^{2}$, Yusuf Hanafi ${ }^{1}$, and Nila \\ Zaimatus $^{3}$ \\ ${ }^{1}$ Faculty of Letters, State University of Malang, Malang, Indonesia \\ ${ }^{2}$ Faculty of Social Sciences, State University of Malang, Malang, Indonesia \\ ${ }^{3}$ Faculty of Islamic Education, State Institute for Islamic Studies, Kediri, Indonesia
}

Corresponding Author:

Titis Thoriquttyas

titisthoriq.fs@um.ac.id

Published: 11 November 2020

Publishing services provided by Knowledge E

(c) Titis Thoriquttyas et al. This article is distributed under the terms of the Creative Commons Attribution License, which permits unrestricted use and redistribution provided that the original author and source are credited.

Selection and Peer-review under the responsibility of the IC-HEDS 2019 Conference Committee.

\section{Abstract}

In Indonesia, the dissemination of religious radicalism not only occurs in educational institutions but has also spread into other social institutions. In the scope of higher education, the National Counter Terrorism Agency (BNPT) released the results of their research in 2018, indicate the emergence of radicalism in several state universities. Although several other parties questioned the details of BNPT's findings, the research made "politics of fear" after explicitly labelling seven well-known state universities exposed to radical ideology. This research is directed to formulate the learning innovation on Islamic Religious Education (IRE) based Civic Intelligence using the Values Clarification Technique (VCT) learning model as an effort to strengthen religious moderation. This research is classified into the research and development (R\&D) model which conducted at State University of Malang (UM) and the development model used the ADDIE model. The result revealed that the mapping for religious moderation after getting treatment can be grouped into five categories (very high: 9.97\%, high: 9.30\%, moderate: $51.82 \%$, low: $26.57 \%$ and very low: $2.32 \%)$.

Keywords: Civic Intelligence, Moderation, Islamic Religious Education

\section{Introduction}

Prejudices and claims of universities as the center and seeds of radicalism emerged after the National Counter Terrorism Agency (BNPT) released the results of its research in 2018 on indications of the emergence of radicalism in several State Universities. Although some other parties questioned the details of BNPT's findings, for example related to the research methodology, data and definitions used, the research made "politics of fear" after explicitly mentioning seven well-known state universities exposed to radical ideology [Oktiana, 2018]. Responding to the BNPT report, Minister of Research, 
Technology and Higher Education, Mohamad Nasir, stated that the potential for spreading radicalism was not only on the seven campuses presented by the National Counterterrorism Agency (BNPT) [Oktiana, 2018] and it needed serious attention from various parties. In addition to the BNPT findings above, the public was also shocked by the news of the arrest of three alumni of Riau University (UNRI) by Detachment 88, who allegedly assembled four bombs to detonate a number of places. Both examples of the report show that radicalism and intolerance have entered into the world of higher education in Indonesia.

Therefore, State University of Malang (UM) as "The Learning University", always provides solutive offers for various challenges related to national issues, one of which is in the form of "Defending the Country" training in order to strengthen the construction of Nationalism and for new coming students who are directed also to strengthen understanding of moderation in social life. The training model is believed to be able to foster civic intelligence in life [Idharoelhaq, 2019]. The character of Civic intelligence is not only a monopoly for certain scientific disciplines, such as Citizenship Education but it shared task by other scientific disciplines [Suryani, 2018], such as Islamic Religious Education (IRE). The involvement of IRE in developing the character of civic intelligence is considered playing the important, because the emergence of events nuanced by radicalism is often related to religious understanding that is exclusive and rigid and dry from the touch of national values [Suryani, 2018].The assumption that the researcher wants to raise regarding the above problematics is that it is necessary to reinforce subjects that are related to strengthening national values. For example, Pancasila, citizenship, history, social science and Religious Education must be strengthened with the national context [Anwar, 2019; Ardiansyah, 2019]. This research will offer its novelty in the form of study slices directed at Civics and Islamic Education courses with a focus on Civic Intelligence in Higher Education that is expected to be able to strengthen UM efforts and the Ministry of Research and Technology's program as an effort to strengthen religious moderation that leads to counter-radicalization forms for student in Higher Education.

The selection of the term "strengthening religious moderation" by the researcher by considering the stages contained in the form of counter radicalization which emphasizes the preventive process rather than curative [Asnawan, 2018; Azami, 2018]. The preventive process is considered by researchers to be more effective in cutting the cycle of understanding of religious radicalism, especially for students [Mansouri, 2019; Azami, 2018]. 
In detail, this research is considered important because it can produce the development character models of civic intelligence in the IRE by optimizing the learning method of Value Clarification Technique (VCT) [Parmiti, 2018]. The selection of the VCT learning method is motivated by the style and characteristics that have optimal biases when applied to the IRE and Civic Education [Azami, 2018; Bhakti, 2018], which go through the stages of choosing, deciding, communicating, solving problems and having problems. establishment in making decisions, so as to be able to internalize and behave in accordance with the values that have been chosen and believed to be in accordance with the values of nationalism. Specifically, the problems that are the focus of the this research can be formulated in the following research questions: How is the development's design of IRE based on civic intelligence through the VCT model for UM students?, How is the contribution of the development of IRE based on civic intelligence through the VCT model be able to contribute in efforts to strengthen religious moderation for UM students?; How is the input obtained through expert testing, limited group testing, and field testing related to the development of the Civic Intelligence-based IRE that is able to contribute as strengthening religious moderation for UM students?

\section{Methods}

This development research is adapted to the flow or design of research based on ADDIE. Respondents in this study were students of State University of Malang (UM) academic year 2019-2020 who took IRE with a sample size of approximately 50\% of the total student respondents.

Data in this study can be classified into two categories: qualitative and quantitative. Qualitative data in the form of questionnaire results and input from students, validator comments and or suggestions. While quantitative data comes from the results of validation from expert validators about product validity, product practicality assessment instruments, and product effectiveness assessment instruments from lecturers and students. The research data collection instruments used consisted of interview guides, observation guides, questionnaires, and expert assessment formats for qualitative data collection and tests for quantitative data collection. Data sources for product effectiveness testing are lecturers and students.

In this study, data collection was carried out through observation, surveys and interviews in the field regarding the development of Civic Intelligence-based IRE through the 
VCT model as an effort to counter religious radicalization. Data collection techniques in this study include: survey and study documentation.

\section{Discussion}

\subsection{The validity and reliability test}

Validity test in this study uses construct validity, which is the correlation between item scores and total scores - which is the sum of each item score - that is sought by the Pearson Product Moment formula. If the scores of all statement items arranged according to the concept dimension is correlate with the total score, then it can be said that the instrument is valid. Decision making by comparing the rcount with rtabel scores. When $r$ count $>$ rtable, the item is valid. Conversely, if $r$ count $<$ rtable, it can be stated that the item is invalid.

In testing of validity and reliability, the researchers took a sample of 301 students as respondents to fill the questionnaire with the number of instruments 20 items. Following are the results of data analysis on religious moderation among Students inputted and analyzed using the Microsoft Excel and IBM SPSS Statistics 21 for Windows software in testing the validity and reliability of the instrument.

Decision making to determine valid items is used $r$ count compared to rtable with dk number of samples minus variables, which in this case must be 2 (two), namely item scores and total scores. Based on table $r$ with dk 229 significant level $(\alpha) 0.05$ is obtained rtable score: $0.05 ; 229$ of 0.1131 . Then, this value is compared with the score in the column "Correlation of item scores - total score". From this comparison it can be seen that in the Religious Moderation questionnaire among Students there are 15 statement items that have values $>0.1131$ (items 1, 2, 4, 6, 8, 10, 11, 12, 13, 14, 16, 17, 18 , 19, and 20), so that a decision can be taken that the 15 statement items are said to be valid. While the remaining 5 items (items $3,5,7,9$, and 15) statement declared invalid because it has a value $<0.1131$.

As for the reliability test in this study, the researchers used an internal consistency test technique, namely the Alpha Cronbach technique. So that in making decisions obtained by comparing the alpha coefficient score (Alpha Cronbach) with rtable score. If the alpha coefficient score is greater than rtable: $0.05 ; 229=0.1131$ then the instrument is said to be reliable, conversely if the alpha coefficient score is smaller than rtable: $0.05 ; 229=$ 0.1131 then the instrument is declared unreliable. 
In the reliability testing, the invalid statements in the instrument items were deleted, an alpha coefficient score of each item (column: Cronbach's Alpha if item deleted) was greater than rtable: $0.05 ; 229=0.1131$. This decision was corroborated by an overall alpha coefficient score of 0.295 which it was greater than $r$ table: $0.05 ; 229=0.1131$, so that it could be concluded that overall, the items on the religious moderation instrument among the students were reliable.

TABLE 1: Reliability Statistics

Cronbach's Alpha

.295

\section{$\mathrm{N}$ of Items}

15

TABLE 2: Item-Total Statistics

\begin{tabular}{|c|c|c|c|c|}
\hline & $\begin{array}{c}\text { Scale Mean if } \\
\text { Item Deleted }\end{array}$ & $\begin{array}{c}\text { Scale Variance if } \\
\text { Item Deleted }\end{array}$ & $\begin{array}{c}\text { Corrected } \\
\text { Item-Total } \\
\text { Correlation }\end{array}$ & $\begin{array}{c}\text { Cronbach's Alpha } \\
\text { if Item Deleted }\end{array}$ \\
\hline VAR00001 & 41.69 & 12.041 & -.008 & .324 \\
\hline VAR00002 & 40.86 & 12.834 & -.101 & .351 \\
\hline VAR00004 & 40.88 & 12.176 & .089 & .281 \\
\hline VAR00006 & 41.28 & 11.829 & .234 & .247 \\
\hline VAR00008 & 41.56 & 12.861 & -.058 & .318 \\
\hline VAR00010 & 41.04 & 11.058 & .230 & .226 \\
\hline VAR00011 & 40.70 & 12.104 & .071 & .286 \\
\hline VAR00012 & 40.83 & 10.299 & .377 & .165 \\
\hline VAR00013 & 42.13 & 11.331 & .095 & .278 \\
\hline VAR00014 & 40.79 & 12.631 & -.033 & .318 \\
\hline VAR00016 & 39.73 & 11.832 & .120 & .270 \\
\hline VAR00017 & 41.30 & 14.578 & -.369 & .214 \\
\hline VAR00018 & 41.97 & 10.236 & .220 & .221 \\
\hline VAR00019 & 40.97 & 10.686 & .329 & .284 \\
\hline VAR00020 & 41.15 & 11.281 & & .22 \\
\hline
\end{tabular}

\subsection{The Pre and Post Treatment: A Comparative Score}

The obtained data through the distribution of questionnaires to the respondents (301 students) after educating on religious moderation shows the differences than before. From the distribution of questionnaire was obtained the post test results for an average (mean) of 70.42, which previously was 59.58; midpoint (median) $=70.00$, which previously was 59.00; level of data spread (variance) $=3,704$, which previously was 9,099; standard deviation $=1,925$, which was previously 3,019; range (range) $=11$, which was previously 18 ; minimum score of data $=66$, which was previously 50 ; and the maximum 
score of data $=77$, which was previously 68. While the total score of 21196 , which previously was 18016 . For more details, it can be seen in the table 3 and 4 :

TABLE 3: Descriptive table for religious moderation (pre-treatment)

\begin{tabular}{|c|c|c|}
\hline \multicolumn{3}{|c|}{ Statistics } \\
\hline $\mathrm{N}$ & Valid & 301 \\
\hline & Missing & 0 \\
\hline Mean & & 59.85 \\
\hline Median & & 59 \\
\hline Std. Deviation & & 3.016 \\
\hline Variance & & 9.099 \\
\hline Range & & 18 \\
\hline Minimum & & 50 \\
\hline Maximum & & 68 \\
\hline Sum & & 18016 \\
\hline
\end{tabular}

TABLE 4: Descriptive table for religious moderation (post-treatment)

\begin{tabular}{|c|c|c|}
\hline \multicolumn{3}{|c|}{ Statistics } \\
\hline $\mathrm{N}$ & Valid & 301 \\
\hline & Missing & 0 \\
\hline Mean & & 70.42 \\
\hline Median & & 70 \\
\hline Std. Deviation & & 1.925 \\
\hline Variance & & 3.704 \\
\hline Range & & 11 \\
\hline Minimum & & 66 \\
\hline Maximum & & 77 \\
\hline Sum & & 21196 \\
\hline
\end{tabular}

TABLE 5: The converting raw scores (five scales).

\begin{tabular}{|c|c|}
\hline Calculation & Result \\
\hline $70.42+1.5(1.925)$ & 73.3075 \\
\hline $70.42+0.5(1.925)$ & 71.3825 \\
\hline $70.42-0.5(1.925)$ & 69.4575 \\
\hline $70.42-1.5(1.925)$ & 67.5325 \\
\hline
\end{tabular}

\begin{tabular}{|c|}
\hline Score \\
\hline Score $>73.3076$ \\
\hline $71.3826<$ Score $<$ \\
73.3075 \\
\hline $69.4576<$ Score $<$ \\
71.3825 \\
\hline $67.5326<$ Score $<$ \\
69.4575 \\
\hline Score $<67.5325$
\end{tabular}

Classification
Very High
High
Middle
Low
Very Low

Based on the calculation above, the data obtained from respondents ( 301 students) on their views for religious moderation post-treatment can be grouped into five categories (very high, high, moderate, low and very low categories). From the frequency distribution 
data, there were 30 respondents from 301 students with a percentage of $9.97 \%$ stated that their religious moderation was very high, 28 respondents with a percentage of 9.30\% stated the religious moderation was high, 156 respondents with a percentage of $51.82 \%$ stated the religious moderation was sufficient, 80 respondents with a percentage of $26.57 \%$ stated the religious moderation is low, and 7 respondents with a percentage of $2.32 \%$ stated the religious moderation is very low. After knowing the categorization above, it needs to know the criteria for religious moderation among students with true score categorization. The true score category can be obtained by finding the highest likelihood score and the lowest likelihood score from the respondent's answer score. Furthermore, the difference between the largest and smallest scores is divided by the desired category, the results of which are used to determine class intervals in making categorization guidelines.

\subsection{The Interpretation for religious moderation's score}

From the respondent's answers after being given guidance related to religious moderation, it is known that the highest possible score is 77 and the smallest score is 66 . The difference between the two is 11 . Then, the difference is divided by the number of categories that have been determined namely 5 , very low, low, sufficient, high, and very high, the result of 2.2 . From these calculations, the true score category as in the following table:

TABLE 6: Interpretation for true score of religious moderation

\begin{tabular}{|c|}
\hline No. \\
\hline 1. \\
\hline 2. \\
\hline 3. \\
\hline 4. \\
\hline 5.
\end{tabular}

\begin{tabular}{|c|}
\hline Interval \\
\hline $66-68.2$ \\
\hline $68.2-70.4$ \\
\hline $70.4-72.6$ \\
\hline $72.6-74.8$ \\
\hline $76.8-77$ \\
\hline
\end{tabular}

\begin{tabular}{|c|}
\hline Classification \\
Very low \\
Low \\
\hline Middle \\
High \\
Very High
\end{tabular}

Based on the true score table above, religious moderation among students are included in the sufficient category. Because of, the average value of religious moderation for students is 70.42 included in the third class, is the interval 70.4 to 72.6 .

\section{Conclusion}

This research shows that optimizing for strengthening of religious moderation are able to involve the multidisciplinary studies, such as civic education. The dimension of civic 
education in this study is represents the study for civic intelligence in IRE especially for Higher Education. Based on the result above, the researchers uncover the scale of religious moderation can be elevate through involving the civic intelligence and values clarification technique as the effort to strengthening the religious moderation.

\section{Funding}

This work was supported by PNBP Research Grant from Univesitas Negeri Malang, 2019.

\section{Acknowledgement}

The authors would like to thank their colleague for their contribution and support to the research. They are also thankful to all the reviewers who gave their valuable inputs to the manuscript and helped in completing the paper.

\section{Conflict of Interest}

The authors have no conflict of interest to declare.

\section{References}

[1] Anwar, S. (2019). Pendidikan Islam dalam Membangun Karakter Bangsa di Era Milenial. Al-Tadzkiyyah: Jurnal Pendidikan Islam, vol. 9, issue 2,

[2] Ardiansyah, M. Z. (2019). Higher-Order Thinking Skills: Strategi Kontra Radikalisme Santri Pesantren. Ibriez: Jurnal Kependidikan Dasar Islam Berbasis Sains, vol. 3, issue 2

[3] Azami, T. (2018). Kurikulum PAl kontra radikalisme: studi kasus di MA Al-Asror Semarang (PhD Thesis). UIN Walisongo.

[4] Bhakti, Y. B., Astuti, I. A. D., Rasjid, H. and Nasution, S. (2018). Penyuluhan Pengintegrasian Nilai Karakter dalam Pembelajaran Berbasis Kurikulum 2013 di Sekolah. J-ABDIPAMAS (Jurnal Pengabdian Kepada Masyarakat), vol. 2, issue 2

[5] Idharoelhaq, A. M., \& Aziz, M. T. (2019). Revitalisasi Pendidikan Karakter melalui Islamisasi Kampus di Universitas Muhammadiyah Sukabumi. Al-Tadzkiyyah: Jurnal Pendidikan Islam, vol. 9, issue 2 
[6] Isnawan, F. (2018). Program Deradikalisasi Radikalisme dan Terorisme Melalui NilaiNilai Luhur Pancasila. FIKRI: Jurnal Kajian Agama, Sosial dan Budaya, vol. 3, issue 1

[7] Mansouri, F., \& Keskin, Z. (2019). Introduction: Framing the Debate Around Islamic Theology, Radicalisation and Violent Extremism. Dalam Contesting the Theological Foundations of Islamism and Violent Extremism. Springer.

[8] Oktiana, E., Putranti, I. R., \& Dir, A. A. B. (2018). Kerjasama BNPT dan Terrorism Prevention Branch (TPB) UNODC dalam Mencegah Paham Radikal dan Tindak Kejahatan Terorisme di Indonesia. Journal of International Relations

[9] Suryani, N. (2018). VCT (Value Clarification Technique) Learning Model Application to Improve Historical Value Understanding. Historia: Jurnal Pendidik dan Peneliti Sejarah, vol. 11, issue 2,

[10] Parmiti, D. P. (2018). The Effect of Value Clarification Technique (VCT) using Contextual Problem Content on Social Attitude and Social Science Learning Achievement of the Elementary School Students. SHS Web of Conferences (Vol. 42, hIm. 00092). EDP Sciences. 